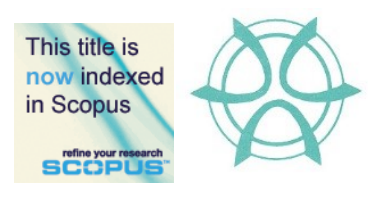

PLANNING MALAYSIA:

Journal of the Malaysian Institute of Planners

VOLUME 19 ISSUE 3 (2021), Page 283 - 294

\title{
AN INVESTIGATION OF THE ISSUES OF TENANCY MANAGEMENT PRACTICE: THE CASE OF COMMERCIAL WAQF PROPERTIES IN MALAYSIA
}

\author{
Ibrahim Sipan ${ }^{1}$, Farah Nadia Abas ${ }^{2}$, Noor Azimah Ghazali ${ }^{3}$, Ahmad Che Yaacob ${ }^{4}$ \\ ${ }^{1,2,3}$ Center of Real Estate Studies, (CRES UTM), Faculty of Built Environment \\ and Surveying, \\ ${ }^{4}$ Faculty of Islamic Civilization, \\ UNIVERSITI TEKNOLOGI MALAYSIA
}

\begin{abstract}
This paper concerns the sustainability of the commercial waqf properties (CWP) in regards to tenancy management (TM) since the waqf properties were underperformed due to large rental arrears in some states. The objective of the study is to investigate the issues of tenancy management that limit the achievement of the financial sustainability of CWP. This research adopts the qualitative approach which employing in-depth interviews at seven (7) CWP as a case study that covered the state of Johor, Selangor, Penang and WPKL. Semistructured interviews were conducted with six (6) waqf property managers (WPM) and twenty-one (21) tenants to get their perspective regarding the issues of tenancy management according to TM attributes. From the findings, it was found that the tenancy businesses attribute is the most issues voiced by the tenants and WPMs followed by tenancy agreement, rental determination and enforcement. Meanwhile, tenant selection and waqf property manager attributes are less critical. Hence, the solutions have been proposed to improve the sustainability of CWP while Shariah principles and waqf needs are being adhered to in the full spectrum of waqf tenancy management.
\end{abstract}

Keywords: commercial waqf properties (CWP), rental arrears, tenancy management, Shariah compliance, waqf needs

\footnotetext{
${ }^{1}$ Professor at University Technology Malaysia Email: ibrahimsipan@utm.my
} 
I. Sipan, F. N. Abas, N.A. Ghazali and A. C. Yaacob

An Investigation of The Issues of Tenancy Management Practice: The Case of Commercial Waqf Properties in Malaysia

\section{INTRODUCTION}

In Malaysia, numerous commercial waqf properties (CWP) have been developed by State Islamic Religious Council (SIRCs) in their vicinity respectively with the cooperation of Department of Awqaf, Zakat and Hajj (JAWHAR) and Waqf Foundation of Malaysia (WFM). CWP could be income generating to the SIRCs through rent and encouraging better economic growth for Muslim society. By having a good cash flow, it will allow the SIRCs to be financially sustainable to cover all the costs and expenses of CWP and also profit distribution for waqf philanthropy. Unfortunately, the statement fails to materialize because the waqf properties were underperformed due to large rental arrears in some states (Mohsin and Mohammad, 2011; Majid and Said, 2014; Ali et al., 2016). Series 3 of the Auditor-General Report 2014 confirmed that some SIRC faced outstanding rental issues; Kedah Islamic Religious Council (MAIK) (RM1,050,000), Penang Islamic Religious Council (MAIPP) (RM4,560,000) and Melaka Islamic Religious Council (MAIM) (RM420,083).

In regards to this issue, several researchers have made recommendations on the improvement of tenancy management in waqf properties. Ismail et al. (2015) suggested that (i) rental of waqf land should be increased in tandem with the current rental value, (ii) more staff should be hired to collect rental more efficiently and (iii) records system of waqf land and tenants must be up to date. While, Osman et al. (2015) urged that tenancy management should be well managed including leasing and renting existing land and buildings, internal and external expertise, selecting and upgrading potential lots. However, the disciplinary studies that deal with the management of waqf tenancy in the full spectrum are scarce.

In another context, the literature also pointed the tenancy management which complied with Shariah and waqf needs. Othman (1982) and Rani and Aziz (2010) examined in depth the management of waqf properties based on the waqf requirements and the Shariah laws embodied in them. They suggested the solutions based on Shariah features which included terms of waqf tenancy, duration, rental rate, the income of waqf properties, tenancy agreement and mutawwali. However, some attributes such as tenant selection, default rent and non-compliance penalties do not exclusively specify. Therefore, this study bridges the gap highlighted in a prior study by interpreting the full spectrum of tenancy management listed as (i) tenant selection, (ii) tenancy businesses, (iii) rental determination, (iv) tenancy agreement, (v) enforcement and (vi) waqf property manager from the Shariah perspective, investigating the current issues from tenant's and WPM perspectives, apart from offering a solution that meets the needs of waqf and Shariah. 
PLANNING MALAYSIA

Journal of the Malaysia Institute of Planners (2021)

\section{TENANCY MANAGEMENT BASED ON SHARIAH COMPLIANT PERSPECTIVES}

Tenancy management (TM) basically interpreted as tenant-landlord business affairs to sustain the building, its system and business for a lasting period (Iman and Mohamad, 2014). The scope of tenancy management may involve tenant recruitment, tenancy agreement, rental determination, rent review, provision of services including maintenance services to tenants, bill collection, marketing, etc. The entire task should be carried out by the landlord itself or may appoint the property manager on behalf of the landlord. However, property managers are better versed in the legal rights of both the tenant and the owner.

Renting or tenancy in Arabic is termed as al-ijarah, which means wages, rents, services or rewards. According to Islamic law terms, the people who rent are called mu'ajir. While, renting person is called musta'jir (Mohamed, 2001). The rented property is termed $m a^{\prime} j u r$ and rent or reward for the use of the goods is called ujrah. From some of the meanings of the ijarah mentioned above, it can be taken as the essence that ijarah or tenancy is an agreement on benefits in return. As such, the tenant hired for a specified period, but actually they do not own the property. They only enjoy the benefit from the property and by the time rental is paid as a return for the enjoyment of benefit.

Since waqf is one of the Islamic philanthropy tools, adherence to Shariah principles are necessitated for the accomplishment of waqf philosophy Ghazali, et.al., (2021). Shariah primary sources, namely the Quran's injunctions and the Prophet s.a.w directives and practices, usually called the Sunnah. While it is possible to refer to the secondary sources of Shariah based on human interpretation and reasoning, whether at the highest level of ijma' (consensus of all jurists) or in the form of qiyas, istihsan, istislah, etc. (Engku Ali, 2013). Shariah compliance generally means adherence to the Shariah principles and conformity to them.

In the context of tenant selection attributes, tenant and landlord conditions are the same with seller and buyer conditions in Islamic law. Mansor (1998) has listed the conditions which are; (i) from those who can be held accountable - sound minded, age, and intelligence (rusyd), (ii) not blocked from managing muamalat (not bankrupt and not safih), (iii) not being forced by any party to carry out the contract. Besides, according to Paragraph (5/1/3) of SS9 stated that if the use to be made of usufructs of rented assets considered permissible, an Ijarah contract could be grant even with a non-Muslim (AAOIFI, 2015). However, if the landlord knows or has reason to assume in advance that the use of the asset to be rented is for an unacceptable purpose, and thus it will not be allowable.

For tenancy businesses attributes, the factors to be considered in businesses condition are permissibility of use according to Shariah law. The permissibility to rent an asset is based on the permissibility of the tenant's core 
I. Sipan, F. N. Abas, N.A. Ghazali and A. C. Yaacob

An Investigation of The Issues of Tenancy Management Practice: The Case of Commercial Waqf Properties in Malaysia

activity, although it may involve certain activities that do not comply with Shariah (No 63) of BNM (2009). The tenant shall comply with the terms and conditions of use of the asset until the expiry of the tenancy or termination of the tenancy as agreed by both parties, whichever is earlier (No 64) of BNM (2009). Furthermore, the property shall not be rented to a person or entity if it is known or if there is a very high potential to use the assets for non-conforming activities (No 68) (BNM, 2009).

In discussing rental determination attributes, the rental amount shall be determined when the tenancy contract is concluded as stated in Paragraph 76 of (BNM, 2009). Once the tenancy agreement comes into effect, the amount of rental specified and mutually agreed for the tenancy period shall not vary during the period (Paragraph 77) of (BNM, 2009). Any variation such as rental benchmarked to market rate or index is prohibited. Usmani (2000) asserted that the landlord shall not increase the rent unilaterally because it would render the agreement null and void. However, it's only could permissible upon renewal of the contract for subsequent tenancy periods that should reflect the market rate or an agreed benchmark (Paragraph 5/2/5) of SS9 (AAOIFI, 2015). Paragraph $(5 / 2 / 4)$ of SS9 states that there are two specified parts of rental, (i) transferred to the landlord and (ii) expenses or costs approved by the landlord, such as the cost of major maintenance, insurance, etc (AAOIFI, 2015). The excess of the second part of the rental shall be treated as an advance to the landlord on the account, while the landlord shall bear any shortage.

Furthermore, in tenancy agreement attributes, legally enforceable contract or al- 'aqd shall consist principles of offer, acceptance, obligations and consideration (Mohamed, 2001). Once an offer is accepted, then a contract is concluded. An offer can be made, either verbal, in writing or could be communicated through messenger. Then, the obligation is an essential principle could involve one relationship with Allah. According to Mohamed (2001), any consideration which is forbidden by the Shariah, renders the contract to be invalid. Therefore, to be a valid tenancy contract, all elements that prohibited by Islamic Law in connection with the consideration of usufruct or manfaah shall take into account. There are several conditions that are deemed as valid contract. Firstly, the tenant and the landlord must be legally able to contract as contracting parties. Secondly, the premises to be rented must be identified in terms of the location, accessibility, facilities, size and quality of the premises. Besides, the rental must be determined and the period of use the premises must be explicit at the time of the contract. Therefore, SS9 of Ijarah under Paragraph (4/1/2) stated that Ijarah's period should start on the date the contract is executed. If the two parties agree on a specified future start date, which will result in a future Ijarah, i.e., an Ijarah contract to be executed in the future (AAOIFI, 2015).

In regards to the rental payable, the tenant shall pay once he/ she has taken delivery of the asset. However, the tenant is not liable for rental during the 
PLANNING MALAYSIA

Journal of the Malaysia Institute of Planners (2021)

period of delay on the part of the owner in delivering the asset. If the contract does not specify when rental is to be tendered then rental is payable on a daily basis if so, demanded by the landlord. In addition, another condition has been listed is the purpose of the tenant to use the premises. The tenant may not conduct business which cause damage to the premises or if the landlord specifically prohibits business or stipulates the type of business permitted. Simply put, the tenant shall use the property only for the purpose specified in the tenancy agreement. However, in the case whereby the agreement does not specify the purpose of the tenancy, the tenant may use the property for whatever permissible purpose according to the customary practice of the market which is in compliance with sharia (BNM, 2009; Mohamed, 2001). The tenant cannot use the property for any abnormal purpose unless the landlord agrees in express terms for such abnormal use (Elias, 2001). Hence, the tenant shall obtain consent from the landlord if the property is to be used for for non-specified use in the customary practice of the market (No. 67) (BNM, 2009).

In respect to enforcement attributes, there are two situations which the rental payment shall be deemed as a debt due from the tenant. First, the debt results from the tenant failure or delay to pay the rental Paragraph (92) of (BNM, 2009) and second, tenant stops using the property or returns it to the owner without the owner's consent (Paragraph 7/1/7) of SS9 (AAOIFI, 2015). According to Paragraph (7/2/2) of SS9, a termination of the tenancy shall be undertaken resulting from the tenant failed or delay to pay the rental (AAOIFI, 2015). Hence, the tenant shall be subject to all the rules prescribed for defaults and delinquencies in the payment of debt for the defined tenancy period. However, the landlord shall not charge any additional amount as income in case of delays in payment of the rental by tenant (Paragraph 6/3) of SS9 and Paragraph 92 of (BNM, 2009).

As far as the second situation is concerned, the rental will continue to be due for the remaining Ijarah period. For this period, the landlord may not rent the property to another tenant, but must keep it at the current tenant's disposal. It should not, however, be carried out if the tenant gives the remaining time to the landlord, in which case the tenancy expires. However, any compensation for actual loss incurred as a result of default and debt payment delinquencies may be claimed by the landlord rather than a rental increase (Paragraph 92) of (BNM, 2009). It also can be regarded as penalty imposed that will be channeled to charity. However, if the tenant wants to be exempted from this penalty, the claim of non-delinquent insolvency should be proven. To be summary, as result from the default payment, the tenancy may not renew and the rental amount outstanding including penalty charges becomes an outstanding debt. 
I. Sipan, F. N. Abas, N.A. Ghazali and A. C. Yaacob

An Investigation of The Issues of Tenancy Management Practice: The Case of Commercial Waqf Properties in Malaysia

\section{METHODOLOGY}

The heterogeneous purposive sample of the case study was adopted in this research which focused on the characteristics of a population and the objective of the study. Thus, the multiple case studies of CWP were selected which covered the state of Johor, Selangor, Penang and WPKL. Overall, seven (7) CWP in four states in Malaysia were used as the case study due to certain criteria like the diversity of commercial types, types of governance, strength and weaknesses of rental performance. It included shop houses, shop office, waqf community bazaar, healthcare centers, business centers and stratified commercial offices.

\section{RESULTS AND FINDINGS}

Qualitative technique through semi-structured interviews was conducted with waqf property manager and the tenants. This approach is undertaken to investigate the tenancy management issues according to TM attributes from both sides. Overall, there are 27 participants involved in this instrument. It was categorized into six (6) WPMs and twenty-one (21) tenants who agreed to be interviewed. The identified tenancy management issues were shown in the following Table 1. By considering the full spectrum of tenancy management, the attributes of tenancy management were segmented into (i) tenant selection, (ii) tenancy businesses, (iii) rental determination, (iv) tenancy agreement, (v) enforcement and (vi) waqf property manager. Four selected states were coded as $\mathrm{A}, \mathrm{B}, \mathrm{C}$ and $\mathrm{D}$.

Table 1: WPM and tenant's perception of tenancy management issues

\begin{tabular}{llc}
\hline Attributes & \multicolumn{1}{c}{ Tenancy Management Issues } & Perspective \\
\hline $\begin{array}{l}\text { A: Tenant } \\
\text { Selection }\end{array}$ & $\begin{array}{l}\text { Tenant Criteria } \\
\text { Easy to deal with non-Muslim previously rather than } \\
\text { Muslim (C) }\end{array}$ & WPM \\
\hline $\begin{array}{l}\text { B: Tenancy } \\
\text { Businesses }\end{array}$ & $\begin{array}{l}\text { Business Condition } \\
\text { The tenant does not display their business license } \\
\text { issued by CCM at the premises (A) }\end{array}$ & WPM \\
& $\begin{array}{l}\text { Business Strategy } \\
\text { The sale of business is seasonal especially during }\end{array}$ & Tenant \\
& $\begin{array}{l}\text { Friday prayer and festival of Hari Raya (B) } \\
\text { Business Strategy }\end{array}$ & Tenant \\
& $\begin{array}{l}\text { The sale of business is seasonal especially during the } \\
\text { school holiday, and festival (Hari Raya) (C) }\end{array}$ & \\
& $\begin{array}{l}\text { Businesses Location, Facilities and services } \\
\text { (Location) }\end{array}$ & WPM \\
& A premise is not strategically located (A) & \\
&
\end{tabular}


PLANNING MALAYSIA

Journal of the Malaysia Institute of Planners (2021)

\begin{tabular}{|c|c|c|}
\hline & $\begin{array}{l}\text { Parking } \\
\text { No available parking causes the difficulties of } \\
\text { customers to come }(\mathrm{C})\end{array}$ & Tenant \\
\hline & $\begin{array}{l}\text { Building Services } \\
\text { Passengers waiting time for lift services is too long } \\
\text { (D) }\end{array}$ & Tenant \\
\hline & $\begin{array}{l}\text { Marketing } \\
\text { No signboard provided before reaching the premises } \\
\text { (B) }\end{array}$ & Tenant \\
\hline & $\begin{array}{l}\text { Marketing } \\
\text { Many obstacles from local authority as such cannot } \\
\text { put the signboard in front of the premises }(C)\end{array}$ & Tenant \\
\hline $\begin{array}{l}\text { Rental } \\
\text { Determination }\end{array}$ & $\begin{array}{l}\text { Rental Collection } \\
\text { The tenant paid the rental through the system but as } \\
\text { there is a problem with the system, no payment is } \\
\text { recorded. Hence, it had been recorded as rent arrears } \\
\text { (C) }\end{array}$ & Tenant \\
\hline & $\begin{array}{l}\text { Rental Increment/ renew } \\
\text { Dissatisfaction towards the rental increment (A) \& } \\
\text { (B) }\end{array}$ & Tenant \\
\hline $\begin{array}{l}\text { Tenancy } \\
\text { Agreement }\end{array}$ & $\begin{array}{l}\text { Responsibility } \\
\text { Cleaning \& Maintenance (correction of faults by } \\
\text { tenant) } \\
\text { Premises are not being managed by the tenant and } \\
\text { are in bad condition (A) }\end{array}$ & WPM \\
\hline & $\begin{array}{l}\text { Responsibility } \\
\text { (Repair and maintenance by WPM) } \\
\text { Leaking water pipes due to high usage (D) }\end{array}$ & WPM \\
\hline & $\begin{array}{l}\text { Responsibility } \\
\text { (Repair and maintenance by } \boldsymbol{W P M} \text { ) } \\
\text { The tenant carried out the repair either minor or } \\
\text { major by themselves }(\mathrm{C})\end{array}$ & Tenant \\
\hline & $\begin{array}{l}\text { Responsibility (response by WPM) } \\
\text { The tenant delivers their complaint through email. } \\
\text { However, it was a late response from WM (C) }\end{array}$ & Tenant \\
\hline & $\begin{array}{l}\text { Sublet } \\
\text { The premises has been sublet without permission(C) }\end{array}$ & WPM \\
\hline Enforcement & $\begin{array}{l}\text { Rental Default } \\
\text { The tenants will only take an action by approaching } \\
\text { the 3rd notice given (notice of termination). } \\
\text { However, the payment is not a lump sum basis. But } \\
\text { the tenant will pay gradually (B) }\end{array}$ & WPM \\
\hline
\end{tabular}


I. Sipan, F. N. Abas, N.A. Ghazali and A. C. Yaacob

An Investigation of The Issues of Tenancy Management Practice: The Case of Commercial Waqf Properties in Malaysia

\begin{tabular}{lll}
\hline & $\begin{array}{l}\text { Rental Default } \\
\text { Monthly rental is not paid on time/ consistently (A) } \\
\&(B)\end{array}$ & WPM \\
\hline $\begin{array}{l}\text { Waqf } \\
\text { Property }\end{array}$ & $\begin{array}{l}\text { Qualification } \\
\text { No experts in regards to development (A) }\end{array}$ & WPM \\
\cline { 2 - 3 } & $\begin{array}{l}\text { Waqf Disbursement } \\
\text { The manfaah from the rental collection are not } \\
\text { fairly distributed (A) }\end{array}$ & WPM \\
\hline
\end{tabular}

Based on Table 1, the most TM issues voiced by the WPMs and the tenants are tenancy businesses followed by tenancy agreement, rental determination and enforcement. Meanwhile, tenant selection and waqf property manager attributes are less critical. Overall, there are eight (8) tenancy management issues in the tenancy businesses attributes voiced by both WPMs and tenants. More surprisingly, the most TM issues come out from the tenants. It does mean that critical issues in TM are from the tenancy businesses attributes. Therefore, these attributes shall be managed effective and efficiently to influence and give positive impacts to tenant's satisfaction. Besides, the tenancy agreement attributes contribute five (5) TM issues. These are four issues comes from responsibility and one issue from sublet. Hence, it indicates that responsibility embedded in tenancy agreement for both WPM and tenants will influence and gives positive impact to waqf tenancy management.

Rental determination attributes have three (3) TM issues and most of the issues were voiced by the tenants. Most of them are dissatisfied with the rental collection and rental increment implemented by WPM respectively. Therefore, rental determination attributes will influence and gives positive impacts to tenant's satisfaction. However, to ensure sustainable income from waqf properties, the rental should be revised to keep up with the market rate. If there is no increment on the rental, the waqf could not mitigate the loss due to the high cost of management and maintenance. Similarly, enforcement attributes also contribute three (3) TM issues. Obviously, the issues of rental default were most voiced by the WPM. Most of the tenants were not paid their monthly rental consistently as agreed in the agreement. As mentioned by WPM, the tenants will only take an action by approaching the 3rd notice given which is called as notice of termination. However, the payment is not a lump sum basis, but the tenant will pay gradually. If these issues could be addressed, then it will enhance the tenant's satisfaction in tenancy management.

The TM issues for waqf property manager attributes were voiced by the WPM itself. The TM issues voiced are qualification whereby no experts in regards to development of waqf properties. Besides, the WPM admitted that the manfaah from the rental collection are not fairly distributed. It does substantiate that this attribute is significant and gives positive impacts to the tenancy management. Last but not least, TM has only one issue regarding the tenant 
selection attributes. The issue raised from the WPM claimed that it was easy to deal with non-Muslim previously rather than Muslim. Thus, selective tenants should be wisely considered to avoid tenant defaults in the future.

\section{DISCUSSION AND SOLUTIONS}

The researchers have proposed the solutions based on the TM issues tabulated in the previous section. Basically, the first step to select the tenants is by giving the explanation about the nature of waqf philosophy in an understandable way. For tenant selection's attributes, the WPM shall provide clear information about the tenant's criteria and tenant screening needs to be done so that they know whether they are qualified or otherwise. Hence, the market tenants are recommended for the tenant's criteria as the rental income must be sufficient to be distributed to beneficiaries as well as to maintain and manage waqf properties. Non-Muslims are also qualified to rent out since it is permitted by Islamic law. However, priority is given to Muslim tenants.

In regards to tenancy businesses' attributes, all the conditions set forth for waqf premises must conform to Shariah principles. It does imply that the business conducted contradict to sharia principles are considered forbidden. As such there should be no elements of forbidden uses include tobacco and alcohol, pork, interest-based banking, gambling and weaponry. To strategized, this framework suggested that they shall have a good tenant profile that could attract more crowds and promote the waqf building. If possible, set up the main tenant or anchor tenant to attract more people to the waqf building especially for a big commercial centre such as a bank, GLC company, EPF, post office and others. Besides, an interesting event should be organized to attract the crowd. Importantly, the activities performed could reflect the waqf's good image and expose the waqf's principles and benefits to society.

As previously suggested, the waqf istibdal could be carried out to combat the less strategic location of waqf premises. However, istibdal issues must refer to maslahah instead of the potential assets and the decision of the Fatwa Committee by SIRC. Then, the researchers proposed that the services of the waqf properties must be emphasized on the provision of ibadat purposes while adding Shariah value such as the location of musolla. By right, putting the sign of musolla could entice more patrons or customers to business premises. However, every service to be equipped at waqf premises must in line with the intention of waqif but depends on the manager to most potential services. Also, in order to attract visitors and make large sales, the framework proposed that an attractive signboard for the waqf property is essential. By doing this, visitors are aware of the existing waqf properties and the product or services that the premise offered. Moreover, colour scheme for waqf building as building identity could also be as the strategy of marketing. 
I. Sipan, F. N. Abas, N.A. Ghazali and A. C. Yaacob

An Investigation of The Issues of Tenancy Management Practice: The Case of Commercial Waqf Properties in Malaysia

Concerning rental determination's attributes, rental collection for waqf properties suggested that rental payments should be made through a bank transfer (GIRO). A bank giro transfer is a method of transferring money by instructing a bank to directly transfer funds from one bank account to another without the use of physical checks. As the rental default was the most challenging issue faced by WPM, the researchers propose that this type of payment appears capable of disciplining tenants in fulfilling their obligations as waqf tenants. Indeed, their monthly payment could make a huge contribution to the beneficiaries. Hopefully, this alternative payment might decrease SIRC's default tenant figures. Then, the rental increment should be implemented based on market rental. But the full consideration must be given to the new facilities provided by the landlord that based on the tenant's needs and performances of businesses.

Basically, the tenancy agreement's attributes concern for the subattributes of responsibility suggested that the process of maintenance must be sharia compliance such as using halal and good cleaning products. Lastly, for the responsiveness dimension proposed by WPM, it shall be done in a shorter time. For on-site WPM, it should be done within half an hour. Then, it would be two hours of response time if in the case was off site but subjected to the terms and condition. Thus, any complaints or request shall be voiced by any medium and must be followed by filling up relevant form. Then, sublet not allowed to be implemented since it is presumed risky.

Besides, rental default proposed as following; i) issuance of billtriggered to pay-(1st-7th of the month), (ii) after 7 days in rental arrears-(14th of the month)-1st notice, (iii) if fail to pay within 14 days from the 1st notice-(28th of the month)-2nd notice, (iv) Notice of expiry (after 30 days)- LOD-letter of demand. As waqf emphasizes the social welfare, thus there is no harsh approach implemented in enforcement's attributes.

For waqf property manager's attributes, qualification suggested that the tenants shall be a competent and professional, understanding of waqf and Shariah (Islamic expertise/principle) and shall graduate in real estate and have an experience in real estate. Since maintenance should be given priority for distribution even if the waqif has stipulated it or not, this distribution is proposed. The allocation should be channelled to; (i) management and maintenance, (ii) outgoings (quit rent, assessment rate, property tax, fire insurance), (iii) sinking fund (upgrading/ major repair) and (iv) beneficiaries.

\section{CONCLUSION}

The arising issues of TM in the waqf practice have been featured prominently in this research. Tenancy businesses are the most issues voiced by the tenants and WPM followed by tenancy agreement, rental determination and enforcement. Meanwhile, tenant selection and waqf property manager attributes are less noticeable. Evidently, it can be perceived that waqf property is not sustainable 
PLANNING MALAYSIA

Journal of the Malaysia Institute of Planners (2021)

yet since the performance of TM should be more improvised effectively and efficiently. As far as Shariah law is concerned, this research proposed a possible solution guided by Shariah principles. The findings have contributed to the literature since there is a lack of studies on Shariah-compliant tenancy management. Besides, by having a good TM could contribute a more income generation will be and thus unlocking the potential of waqf properties to compete with other conventional properties.

\section{ACKNOWLEDGEMENTS}

The research was funded by National Institute of Valuation (INSPEN) through the research grant of The National Real Property Research Coordinator (NAPREC). We thank our colleagues from Universiti Teknologi Malaysia (UTM) with vote number RJ130000.7327.4B346, and by Fundamental Research Grant Scheme (FRGS) Phase 1/2019: FRGS/1/2019/SSI10/UTM/02/1, Ministry of Education, Malaysia. We thank our colleagues from Universiti Teknologi Malaysia (vote number: 5F202) as the supporting institution that provided insight and expertise that greatly assisted the research

\section{REFERENCES}

AAOIFI (2015). Sharia Standard (SS 33) on Waqf and (SS 9) on Ijarah, Shari'ah Standards for Islamic Financial Institutions Accounting and Auditing Organization For Islamic Financial Institutions.

Ali, S. N. M., Johari, N., Fauzi, N. S., Ahmad, N., Chuweni, N. N. and Noor, A. H. M. (2016). Income Optimization From Waqf Properties: Sustaining The Acheen Street Mosque. e-Proceeding of the Social Sciences Research ICSSR

BNM (2009). Draft Of Shariah Parameter Reference 2: Ijarah Contract (SPR2). (Bank Negara Malaysia).

Elias, A. H. (2001). Business Laws. Transl of Muhammad Madani's Tahseelul Quduri Li Masaail-ul-Quduri (1990). . (Benoni: Jet Printers).

Engku Ali, E. R. A. (2013). Shariah-compliant to Shariah-based financial innovation: a question of semantics or progressive market differentiation. 4th SC-OCIS Roundtable, 9 -10 March 2013, Ditchley Park, Oxford, United Kingdom.

Ghazali, N.A., Sipan, I., Haji Mohammad, M.T.S. and Ab Aziz, M.A. (2021), New framework for the management of waqf land registration system in Malaysia, International Journal of Islamic and Middle Eastern Finance and Management, Vol. 14 No. 3, pp. 625-640. DOI: doi.org/10.1108/IMEFM-04-2019-0172Iman, A. H. M. and Mohamad, M. T. S. (2014). Waqf property: Concept, management, development, and financing. Penerbit UTM Press,

Ismail, C. Z., Salim, N. J. and Hanafiah, N. J. A. (2015). Administration and Management of Waqf Land in Malaysia: Issues and Solutions. Mediterranean Journal of Social Sciences. 6(4), 613.

Majid, R. A. and Said, R. (2014). Permasalahan Pengurusan Hartanah Wakaf Di Malaysia. International Surveying Research Journal (ISrJ). Volume 4 Number 1 29-43. 
I. Sipan, F. N. Abas, N.A. Ghazali and A. C. Yaacob

An Investigation of The Issues of Tenancy Management Practice: The Case of Commercial Waqf Properties in Malaysia

Mansor, M. B. H. (1998). Konsep Syariah Dalam Sistem Perbankan Islam. (BIMB Institute of Research and Training Sdn. Bhd (BIRT)).

Mohamed, S. I. (2001). Rights and Obligations of Landlord and Tenant: A Study in the Light of Shari'ah (Islamic Law) and the South African Rental Housing Act. Citeseer,

Mohsin, A. and Mohammad, M. (2011). Weaknesses of current capital raising, financing, and investment methods of awqaf (Islamic Trusts). International Conference on Social Science and Humanity, Singapore, 2011-02-26, 5: 401-405.

Osman, S., Mat, I., Ahmad, J. and Othman, Y. (2015). Unlocking Value Of Waqf Property Using Hibah Mudharabah: A Case Study Of Commercial Buildings In Kedah, Malaysia. International Journal of Development Research. 5(5), 4294-4299.

Othman, M. Z. (1982). Islamic Law: With Special Reference to the Institution of Waqf. Prime Minister's Department, Religious Affairs Division,

Rani, M. A. M. and Aziz, A. A. (2010). Waqf management and administration in malaysia: its implementation from the perspective of Islamic law. Malaysian Accounting Review. 9, 115-121.

Usmani, M. T. (2000). An Introduction to Islamic Finance. Karachi: Idaratul Ma'arif.

Received: $12^{\text {th }}$ July 2021 . Accepted: $17^{\text {th }}$ Sept 2021 